Article

\title{
In Vitro Anti-Biofilm and Antibacterial Properties of Streptococcus downii sp. nov.
}

\author{
Maigualida Cuenca ${ }^{1,+}{ }^{,}$María Carmen Sánchez ${ }^{1, *,+}{ }^{\circ}$, Pedro Diz ${ }^{2}$, Lucía Martínez-Lamas ${ }^{3}$, Maximiliano Álvarez ${ }^{3}$, \\ Jacobo Limeres ${ }^{2}{ }^{\circledR}$, Mariano Sanz ${ }^{1}$ and David Herrera ${ }^{1}$ (i) \\ 1 ETEP (Etiology and Therapy of Periodontal and Peri-Implant Diseases) Research Group, \\ University Complutense of Madrid (UCM), 28040 Madrid, Spain; maiguacu@ucm.es (M.C.); \\ marsan@ucm.es (M.S.); davidher@ucm.es (D.H.) \\ 2 Medical-Surgical Dentistry Research Group (OMEQUI), Health Research Institute of Santiago de \\ Compostela (IDIS), University of Santiago de Compostela (USC), 15705 Santiago de Compostela, Spain; \\ pedro.diz@usc.es (P.D.); jacobo.limeres@usc.es (J.L.) \\ 3 Clinical Microbiology, Microbiology and Infectology Group, Galicia Sur Health Research Institute, \\ Hospital Álvaro Cunqueiro, Complejo Hospitalario Universitario de Vigo, Vigo, 36312 Galicia, Spain; \\ lu_13128@hotmail.com (L.M.-L.); maximiliano.alvarez.fernandez@sergas.es (M.Á.) \\ * Correspondence: mariasan@ucm.es; Tel.: +34-913-941-674 \\ + These authors equally contributed to this work.
}

\section{check for} updates

Citation: Cuenca, M.; Sánchez, M.C.; Diz, P.; Martínez-Lamas, L.; Álvarez, M.; Limeres, J.; Sanz, M.; Herrera, D. In Vitro Anti-Biofilm and

Antibacterial Properties of Streptococcus downii sp. nov.. Microorganisms 2021, 9, 450. https:// doi.org/10.3390/microorganisms 9020450

Academic Editor: Georgios

N. Belibasakis

Received: 21 January 2021

Accepted: 19 February 2021

Published: 22 February 2021

Publisher's Note: MDPI stays neutral with regard to jurisdictional claims in published maps and institutional affiliations.

Copyright: (c) 2021 by the authors. Licensee MDPI, Basel, Switzerland. This article is an open access article distributed under the terms and conditions of the Creative Commons Attribution (CC BY) license (https:// creativecommons.org/licenses/by/ $4.0 /)$.

\begin{abstract}
The aim of this study was to evaluate the potential anti-biofilm and antibacterial activities of Streptococcus downii sp. nov. To test anti-biofilm properties, Streptococcus mutans, Actinomyces naeslundii, Veillonella parvula, Fusobacterium nucleatum, Porphyromonas gingivalis, and Aggregatibacter actinomycetemcomitans were grown in a biofilm model in the presence or not of $S$. downii sp. nov. for up to $120 \mathrm{~h}$. For the potential antibacterial activity, $24 \mathrm{~h}$-biofilms were exposed to $S$. downii sp. nov for 24 and $48 \mathrm{~h}$. Biofilms structures and bacterial viability were studied by microscopy, and the effect in bacterial load by quantitative polymerase chain reaction. A generalized linear model was constructed, and results were considered as statistically significant at $p<0.05$. The presence of $S$. downii sp. nov. during biofilm development did not affect the structure of the community, but an anti-biofilm effect against $S$. mutans was observed ( $p<0.001$, after 96 and $120 \mathrm{~h}$ ). For antibacterial activity, after $24 \mathrm{~h}$ of exposure to $S$. downii sp. nov., counts of $S$. mutans $(p=0.019)$ and A. actinomycetemcomitans $(p=0.020)$ were significantly reduced in well-structured biofilms. Although moderate, anti-biofilm and antibacterial activities of $S$. downii sp. nov. against oral bacteria, including some periodontal pathogens, were demonstrated in an in vitro biofilm model.
\end{abstract}

Keywords: oral biofilm; Streptococcus downii sp. nov.; caries; Streptococcus mutans; periodontal diseases; Aggregatibacter actinomycetemcomitans

\section{Introduction}

The oral cavity has one of the richest microbial communities within the human microbiome, with around 200 cultivable bacterial species and approximately 1000 phylotypes detected by $16 \mathrm{~S}$ rRNA gene sequencing [1,2]. In healthy subjects, the majority of these species are commensal and maintain a symbiotic relation with the host, being the predominant phyla: Firmicutes, Proteobacteria, Actinobacteria, Bacteroidetes, and Fusobacteria [3]. Among Firmicutes the most abundant species belongs to Streptococcus, Veillonella, and Lactobacillus genera [4]. However, under specific environmental conditions, existing pathobionts may overgrow and become pathogenic, mainly by disturbing the homeostasis between the bacterial challenge and the host immune responses (dysbiosis) [5], which can also be associated with changes in microbial metabolism and/or shifts in bacterial diversity. Moreover, within the oral cavity, overgrow of microorganisms usually occurs forming highly structured poly-microbial communities, as biofilms, what may hinder the efficacy of host defenses and natural antimicrobial strategies. 
Intervention studies have confirmed the etiological importance of biofilms by demonstrating that mechanical biofilm disruption is a key step in the effective management of biofilm-related oral conditions, caries, and periodontal diseases. In the treatment of the most aggressive/severe cases of periodontitis, more effective outcomes have been demonstrated when mechanical debridement has been supplemented with the adjunctive use of antibiotics [6] and antiseptics [7]. The use of antimicrobials, however, is controversial, due to the possible occurrence of secondary effects and the development of bacterial resistances [6-9], which calls for exploring alternative strategies.

One of these alternative strategies is to foster a health-associated microbiota that will transform the dysbiotic state into re-establishing homeostasis. One strategy in this direction has been the use of live microorganisms (probiotics), mainly bifidobacteria and lactobacilli, which have shown adjunctive benefits in the prevention and treatment of periodontal diseases [10-20]. This benefit has been attributed to the ability of these probiotics (i) to occupy a habitat, and thus reduce pathogen adhesion and colonization; (ii) to boost the host immune response; and (iii) since they have inherent antimicrobial activity [21]. Another strategy, seldom explored and investigated, has been the use of indigenous oral species, which will occupy and ecological niche, and thus will reduce the adhesion and growth of opportunistic pathogens and pathogenic species [22-26]. Streptococcus spp., such as Streptococcus sanguinis, Streptococcus cristatus, Streptococcus salivarius, or Streptococcus mitis, have shown their ability to inhibit the in vitro colonization of epithelial cells by Aggregatibacter actinomycetemcomitans [24,25], S. mitis showed antagonism in the adhesion of Porphyromonas gingivalis [23], and Streptococcus dentisani, isolated from caries-free individuals, showed growth inhibition of periodontal pathogens and against pathogens implicated in dental root infections, in pure culture $[22,27,28]$. Moreover, S. dentisani, attached to gingival cells in vitro, inhibits periodontal pathogens by competition, adherence, and displacement mechanisms [28]. Similarly, bifidobacteria may have the capacity of suppressing the growth of $P$. gingivalis by reducing key nutritional factor(s) in the environment [26].

Recently, derived from the analysis of the oral microbiota of patients with Down syndrome a novel species of bacteria of the Streptococcus oralis group, Streptococcus downii sp. nov., has been described [29]. By inhibition assays, S. downii sp. nov. has exhibited a potentially antimicrobial effect against the cariogenic bacteria Streptococcus mutans and against the periodontal pathogens Veillonella parvula and A. actinomycetemcomitans [29].

However, despite the fact that oral bacteria are organized in biofilms, most of these in vitro studies cited have investigated this antibacterial potential against bacteria in the planktonic state, rather than assessing this effect on biofilm models, thus mimicking a situation closer to what happens in vivo. Therefore, based on the results of individual species-species that determined the specific effect on S. mutans, V. parvula and A. actinomycetemcomitans, the purpose of this investigation was to assess (i) the potential anti-biofilm activity of $S$. downii sp. nov., either by inhibiting the growth of selected oral bacteria and/or by interfering with biofilm formation when growing on an in vitro biofilm model, and (ii) the potential antibacterial effects against oral bacteria in mature biofilms.

\section{Materials and Methods}

\subsection{Isolates, Culturing, and Bacterial Growth Conditions}

S. downii sp. nov. strain CECT 9732T, isolated from a supragingival dental biofilm sample of an individual with Down syndrome [29], and the reference bacterial strains S. mutans ATCC 25175, V. parvula NCTC 11810, Actinomyces naeslundii ATCC 19039, F. nucleatum DMSZ 20482, A. actinomycetemcomitans DSMZ 8324, and P. gingivalis ATCC 33277 were used to develop a multi-species biofilm model. Bacteria were cultured anaerobically $(10 \%$ $\mathrm{H}_{2}, 10 \% \mathrm{CO}_{2}$, and balance $\mathrm{N}_{2}$ ) on blood agar plates (Blood Agar Oxoid No 2; Oxoid, Basingstoke, UK), supplemented with 5\% (v/v) sterile horse blood (Oxoid, Basingstoke, UK), $5.0 \mathrm{mg} \mathrm{mL}^{-1}$ hemin (Sigma-Aldrich, St. Louis, MO, USA) and $1.0 \mathrm{mg} \mathrm{mL}^{-1}$ menadione (Merck, Darmstadt, Germany) for $72 \mathrm{~h}$ at $37^{\circ} \mathrm{C}$. 


\subsection{Anti-Biofilm Activity of S. downii sp. nov. in an in Vitro Biofilm Model}

Figure 1 shows the experimental design followed for the study of the anti-biofilm properties of $S$. downii sp. nov. strain CECT 9732T against bacteria in an oral biofilm model.

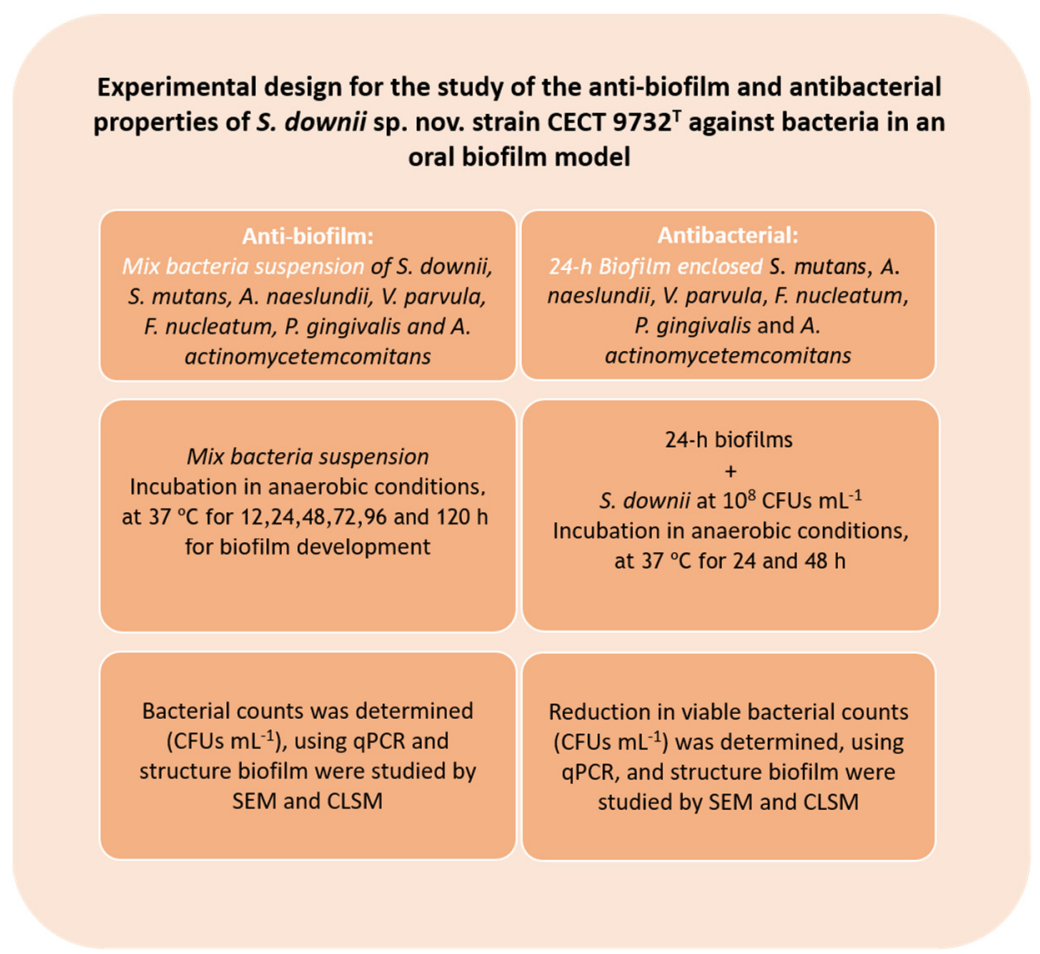

Figure 1. Scheme of the antibacterial assays carried out in the study. For abbreviations, see the text.

\subsubsection{Biofilm Development}

Biofilms were developed on hydroxyapatite (HA) discs in a static biofilm model, based on the model described by Sánchez et al. [30] with some modifications. In brief, representative colonies of all species were selected randomly and were grown on brainheart infusion (BHI) medium (Becton, Dickinson and Company, Franklin Lakes, NJ, USA) supplemented with $2.5 \mathrm{~g} \mathrm{~L}^{-1}$ mucin (Oxoid, Basingstoke, UK), $1.0 \mathrm{~g} \mathrm{~L}^{-1}$ yeast extract (Oxoid, Basingstoke, UK), $0.1 \mathrm{~g} \mathrm{~L}^{-1}$ cysteine (Sigma-Aldrich, St. Louis, MO, USA), $2.0 \mathrm{~g}$ $\mathrm{L}^{-1}$ sodium bicarbonate (Merck, Darmstadt, Germany), $5.0 \mathrm{mg} \mathrm{L}^{-1}$ hemin (Sigma-Aldrich, St. Louis, MO, USA), and $1.0 \mathrm{mg} \mathrm{L}^{-1}$ menadione (Merck, Darmstadt, Germany) and $0.25 \%(v / v)$ glutamic acid (Sigma-Aldrich, St. Louis, MO, USA), in anaerobic condition at $37^{\circ} \mathrm{C}$ for $24 \mathrm{~h}$. The bacterial growth was harvested at late exponential phase (measured by spectrophotometry), and a mixed bacterial suspensions in supplemented BHI medium were prepared in order to develop biofilms, using different starting concentrations, depending on their growth rate: $10^{3}$ colony forming units (CFU) mL $\mathrm{mL}^{-1}$ of $S$. mutans, $10^{5} \mathrm{CFU} \mathrm{mL} \mathrm{m}^{-1}$ of V. parvula and A. naeslundii, and $10^{6} \mathrm{CFU} \mathrm{mL} \mathrm{m}^{-1}$ of $F$. nucleatum, A. actinomycetemcomitans, and P. gingivalis.

Sterile HA discs [7-mm diameter and 1.8 (standard deviation-SD =0.2) $\mathrm{mm}$ thickness (Clarkson Chromatography Products, Williamsport, PA, USA)] were placed in a multiwell tissue culture plate (Greiner Bio-one, Frickenhausen, Germany). Each well was inoculated with $1.5 \mathrm{~mL}$ of the mixed bacterial suspension, and to assess the anti-biofilm activity, treated wells were inoculated with $10^{3} \mathrm{CFU} \mathrm{mL} \mathrm{mL}^{-1}$ of $S$. downii sp. nov. final concentration (recovered at late-exponential phase by centrifugation of an overnight culture and resuspended in fresh modified BHI medium). Control biofilms, not exposed to $S$. downii sp. nov., and treated ones were then incubated in anaerobiosis at $37^{\circ} \mathrm{C}$, for $12,24,48,72,96$, and $120 \mathrm{~h}$. Plates only containing culture media were also incubated to check for sterility. Three independent trials (on three different occasions) were carried out. 


\subsubsection{DNA Isolation and Quantitative Polymerase Chain Reaction (qPCR)}

Before the DNA isolation, discs were sequentially rinsed in $2 \mathrm{~mL}$ of sterile buffer saline (PBS) (immersion time per rinse, $10 \mathrm{~s}$ ), three times, in order to remove non-adherent bacteria. Biofilms were then disrupted by vortex for $2 \mathrm{~min}$ in $1 \mathrm{~mL}$ of PBS. The DNA from the biofilm was extracted using an ATP Genomic DNA Mini Kit ${ }^{\circledR}$ (ATP biotech. Taipei, Taiwan) according to the manufacturer's recommendations. The bacterial 16S rRNA gene sequence was amplified by qPCR, according to the hydrolysis probes 5 'nuclease method (Table 1). The qPCR amplification was performed in a total reaction mixture volume of $10 \mu \mathrm{L}$. The reaction mixtures contained $5 \mu \mathrm{L}$ of $2 \times$ master mixture (LC 480 Probes Master; Roche, Mannheim, Germany), optimal concentrations of primers and probes $(300,300$ and $300 \mathrm{nM}$, respectively, for S. mutans, Streptococcus spp., A. naeslundii and P. gingivalis; 750, 750, and $400 \mathrm{nM}$ for $V$. parvula; 300, 300, and $200 \mathrm{nM}$ for A. actinomycetemcomitans; and, finally, 600,600 , and $300 \mathrm{nM}$ for F. nucleatum) and $2 \mu \mathrm{L}$ of DNA from samples. The negative control was $2 \mu \mathrm{L}$ of sterile water (Water PCR grade, Roche Mannheim, Germany). The samples were subjected to an initial amplification cycle of $95^{\circ} \mathrm{C}$ for $10 \mathrm{~min}$, followed by 40 cycles at $95^{\circ} \mathrm{C}$ for $15 \mathrm{~s}$ and $60^{\circ} \mathrm{C}$ for $1 \mathrm{~min}$. Analyses was performed with a LightCycler ${ }^{\circledR} 480 \mathrm{II}$ thermocycler (Roche Mannheim, Germany). LightCycler ${ }^{\circledR} 480$ Multiwell Plates 384 and sealing foils were used (Roche Mannheim, Germany). Each DNA sample was analyzed in duplicate.

Table 1. Primers and probes used for quantification of genomic DNA from the target bacteria. Primers and probes were targeted against 16S rRNA gene (Obtained from Life Technologies Invitrogen (Carlsbad, CA, USA) and Roche (Roche Diagnostic GmbH; Mannheim, Germany)).

\begin{tabular}{|c|c|c|}
\hline Bacteria & Sequence $\left(5^{\prime}-3^{\prime}\right)$ & Length (bp) \\
\hline \multicolumn{3}{|c|}{ Streptococcus spp. } \\
\hline Forward & CAACGATACATAGCCGACCTGAG & \multirow{3}{*}{97} \\
\hline Reverse & TCCATTGCCGAAGATTCC & \\
\hline Probe & 6FAM-СTCCTACGGGAGGCAGCAGTAGGGA-BBQ & \\
\hline \multicolumn{3}{|c|}{ (1) } \\
\hline Forward & GCCTACAGCTCAGAGATGCTATTCT & \multirow{3}{*}{58} \\
\hline Reverse & GCCATACACCACTCATGAATTGA & \\
\hline Probe & 6FAM-TGGAAATGACGGTCGCCGTTATGAA-TMR & \\
\hline \multicolumn{3}{|c|}{ (2) } \\
\hline Forward & TGCTAATACCGCATACGATCTAACC & \multirow{3}{*}{66} \\
\hline Reverse & GCTTATAAATAGAGGCCACCTTTCA & \\
\hline Probe & 6FAM-CTATCCTCGA+T+GCC+GA-BBQ & \\
\hline \multicolumn{3}{|l|}{ A. naeslundii } \\
\hline Forward & GGCTGCGATACCGTGAGG & \multirow{3}{*}{103} \\
\hline Reverse & TCTGCGATTACTAGCGACTCC & \\
\hline Probe & 6FAM-CCCTAAAAGCCGGTCTCAGTTCGGAT-BBQ & \\
\hline \multicolumn{3}{|c|}{ 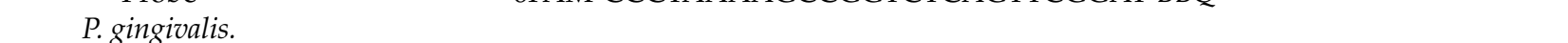 } \\
\hline Forward & GCGCTCAACGTTCAGCC & \multirow{3}{*}{67} \\
\hline Reverse & CACGAATTCCGCCTGC & \\
\hline Probe & 6FAM-CACTGAACTCAAGCCCGGCAGTTTCAA-TAMRA & \\
\hline \multicolumn{3}{|c|}{ A. actinomycetemcomitans } \\
\hline Forward & GAACСTTACСТАСТСТTGACATCCGAA & \multirow{3}{*}{80} \\
\hline Reverse & TGCAGCACCTGTCTCAAAGC & \\
\hline Probe & 6FAM-AGAACTCAGAGATGGGTTTGTGCCTTAGGG-TAMRA & \\
\hline \multicolumn{3}{|l|}{ F. nucleatum } \\
\hline Forward & GGATTTATTGGGCGTAAAGC & \multirow{3}{*}{162} \\
\hline Reverse & GGCATTCCTACAAATATCTACGAA & \\
\hline Probe & 6FAM-CTCTACACTTGTAGTTCCG-TAMRA & \\
\hline
\end{tabular}

Quantification of bacteria by qPCR was based on standard curve. The correlation between $\mathrm{Cq}$ values and CFU mL ${ }^{-1}$ was automatically generated through the software (LC 480 Software 1.5; Roche Mannheim, Germany). Since the primers and probes targeting 
Streptococcus spp. detected all Streptococcus present in the sample, the number of S. downii sp. nov. was calculated by subtracting the number of $S$. mutans.

\subsubsection{Analysis of Biofilms by Confocal Laser Scanning Microscopy (CLSM)}

Biofilms grown on HA discs were stained with LIVE/DEAD ${ }^{\circledR}$ BacLight $^{\mathrm{TM}}$ Bacterial Viability Kit solution (Molecular Probes B. V., Leiden, The Netherlands) at room temperature, with 1:1 fluorocromes ratio, in the dark for $10 \mathrm{~min}(\mathrm{SD}=1)$. The obtained fully hydrated biofilms were studied with a confocal laser scanning microscope, using a fixed-stage Ix83 Olympus inverted microscope, coupled to an Olympus FV1200 confocal system (Olympus; Shinjuku, Tokyo, Japan) with a $\times 63$ water-immersion lenses (Olympus, Shinjuku, Tokyo, Japan). At least three separate and representative locations were selected from the HA discs covered with biofilm. With the use of a dedicated software (Olympus ${ }^{\circledR}$ software (Olympus, Shinjuku, Tokyo, Japan) and Image analysis FIJI ${ }^{\circledR}$ software (Image J v. 2.0.0-rc-65 /1.52b) a z-series of scans (xyz) of $0.5 \mu \mathrm{m}$ thickness ( 8 bits, $1024 \times 1024$ pixels) were analyzed.

\subsubsection{Analysis of Biofilms by Scanning Electron Microscope (SEM)}

Specimens were fixed in a solution at $4 \%$ paraformaldehyde and $2.5 \%$ glutaraldehyde for $4 \mathrm{~h}$, at $4{ }^{\circ} \mathrm{C}$. The discs were washed once in phosphate buffer saline (PBS) and another time in sterile water (immersion time per washed $10 \mathrm{~min}$ ) and then dehydrated through a series of graded ethanol solutions (30, 50, 70, 80, 90, and 100\%; immersion time per series $10 \mathrm{~min}$ ). After that, specimens were critical point dried, sputter-coated with gold and analysed by electron microscopy JSM 6400 (JSM6400; JEOL, Tokyo, Japan) with a back-scattered electron detector and an image resolution of $25 \mathrm{kV}$.

\subsection{Antibacterial Effect of S. downii sp. nov. Against Oral Species in an Already Established in Vitro Biofilm}

Figure 1 presents the experimental design of the study on the antibacterial activity of S. downii sp. nov. strain CECT 9732T against bacteria, in an in vitro oral biofilm model.

\subsubsection{Biofilm Development}

Biofilms were developed as described previously (Section 2.2.1), and a mixed bacterial suspensions in supplemented BHI medium were prepared in order to develop biofilms, containing $10^{3} \mathrm{CFU} \mathrm{mL} \mathrm{m}^{-1}$ of $S$. mutans, $10^{5} \mathrm{CFU} \mathrm{mL}^{-1}$ of $V$. parvula and A. naeslundii, and $10^{6} \mathrm{CFU} \mathrm{mL} \mathrm{m}^{-1}$ of $F$. nucleatum, A. actinomycetemcomitans, and P. gingivalis. HA discs (Clarkson Chromatography Products, Williamsport, PA, USA) and $1.5 \mathrm{~mL}$ of the bacterial suspension were placed in the multi-well tissue culture plate (Greiner Bio-one, Frickenhausen, Germany) and incubated at $37^{\circ} \mathrm{C}$ in anaerobiosis for $24 \mathrm{~h}$. After that, the $24 \mathrm{~h}$ developed biofilms were: (i) exposed to $1 \mathrm{~mL}$ of $S$. downii sp. nov. at $10^{8} \mathrm{CFU} \mathrm{mL}^{-1}$ in supplemented BHI medium or (ii) in the case of controls, exposed to $1 \mathrm{~mL}$ of fresh supplemented BHI medium. Biofilms were then incubated for additional 24 and $48 \mathrm{~h}$ at $37^{\circ} \mathrm{C}$ in anaerobiosis. Three independent trials (on three different occasions) were carried out.

\subsubsection{Biofilm Analysis}

The $24 \mathrm{~h}$ biofilms and the biofilms re-incubated another $24-48 \mathrm{~h}$ in the presence or not (controls) of $S$. downii sp. nov., were analysed. Confocal laser scanning microscopy and scanning electron microscopy (Sections 2.2.3 and 2.2.4) displayed the biofilms structures and bacterial viability. Quantitative polymerase chain reaction was used to assess the effect of $S$. downii sp. nov. in bacterial load (amounts of each bacterium expressed as CFU mL ${ }^{-1}$; Section 2.2.2).

\subsection{Statistical Analysis}

The primary outcome variable was the count of viable bacteria present in the in vitro developed biofilms, expressed as viable CFU $\mathrm{mL}^{-1}$ of $S$. downii sp. nov., S. mutans, V. parvula, A. naeslundii, A. actinomycetemcomitans, P. gingivalis, and F. nucleatum. An 
experiment-level analysis was performed for each parameter of the study $(n=3)$. ShapiroWilk goodness-of-fit tests and distribution of data were used to assess normality. Data were expressed as means and standard deviations (SD).

In order to evaluate the impact of $S$. downii sp. nov. and the time of biofilmdevelopment (up to $120 \mathrm{~h}$ ) and their interaction with the primary outcome variable (counts expressed in $\mathrm{CFU} \mathrm{mL} \mathrm{m}^{-1}$ ), a general linear model was constructed for each bacterial species, using the method of maximum likelihood and Bonferroni corrections for multiple comparisons. A $p$-value $<0.05$ was considered statistically significant. A software package (IBM SPSS Statistics 21.0; IBM Corporation, Armonk, NY, USA) was used for all data analysis.

\section{Results}

\subsection{Anti-Biofilm Activity of S. downii sp. nov. in an in Vitro Biofilm Model}

The impact of $S$. downii sp. nov. on the obtained multispecies biofilms was assessed from 12 to $120 \mathrm{~h}$. Figure 2 depicts the kinetic profiles of the six bacterial species used in this in vitro biofilm model (strains S. mutans, A. naeslundii, V. parvula, F. nucleatum, P. gingivalis, and A. actinomycetemcomitans), quantified by qPCR, when forming biofilms with or without the presence of $S$. downii sp. nov. In biofilms exposed to $S$. downii sp. nov., it could be detected this bacterial species incorporated in the biofilm as early as $12 \mathrm{~h}$ of biofilm evolution and up to $120 \mathrm{~h}$, with an average concentration of $2.7 \times 10^{7} \mathrm{CFU} \mathrm{mL}^{-1}$ $\left(\mathrm{SD}=1.5 \times 10^{7}\right)$.

In both obtained biofilms, with or without the presence of $S$. downii sp. nov, the six bacterial species were incorporated already after $12 \mathrm{~h}$ of incubation, and were present for up to $120 \mathrm{~h}$. Only the growth of S. mutans was significantly different when S. downii sp. nov. was present in the biofilms (Figure 2). This impact was not observed in the early stages of biofilm formation, since at $12 \mathrm{~h}$, both biofilms were similar $(p>0.05)$. From 24 to $72 \mathrm{~h}$ there was a clear trend, but without being statistically significant ( $p>0.05$ in all cases). However, differences were evident and statistically significant in the stationary phase (96 and $120 \mathrm{~h}$ ) of the biofilm formation ( $p<0.001$, in both cases) (Figure 2). The kinetics of the rest of initial colonizers ( $V$. paroula and A. naeslundii), and that of the periodontal pathogens (F. nucleatum, A. actinomycetemcomitans, and P. gingivalis) was not affected by the presence of $S$. downii sp. nov. during the $120 \mathrm{~h}$ of incubation ( $p>0.05$ in all cases).

Biofilm structure and bacterial viability were studied by CLSM. During the initial growth phase, and after $24 \mathrm{~h}$ of incubation, biofilms containing $S$. downii sp. nov. depicted a well-structured bacterial community, similar to biofilms without $S$. downii sp. nov. (Figure 3a,b), with a live/dead ratio of $2.75(\mathrm{SD}=0.2)$ for biofilms without $S$. downii sp. nov. and $2.4(\mathrm{SD}=0.8)$ for biofilms containing $S$. downii sp. nov. This tendency was maintained during the exponential phase of biofilm development and, after $72 \mathrm{~h}$, both modalities of biofilms showed a similar architecture, corresponding to a mature bacterial community (Figure 3c,d), with a live/dead ratio of 3.0 ( $S D=0.1$ ), for biofilms without $S$. downii sp. nov., and $2.7(\mathrm{SD}=0.2)$, for biofilms containing $S$. downii sp. nov. However, and in agreement with the previously described qPCR data, in the stationary phase of biofilms (from 96 to $120 \mathrm{~h}$, Figure 3e,f), it could be observed a higher percentage of dead cells in biofilms containing S. downii sp. nov., when compared with biofilms without $S$. downii sp. nov. The live/dead ratio was $2.0(\mathrm{SD}=0.1)$ for biofilms without $S$. downii sp. nov. and $1.4(\mathrm{SD}=0.4)$ for biofilms containing $S$. downii sp. nov. 

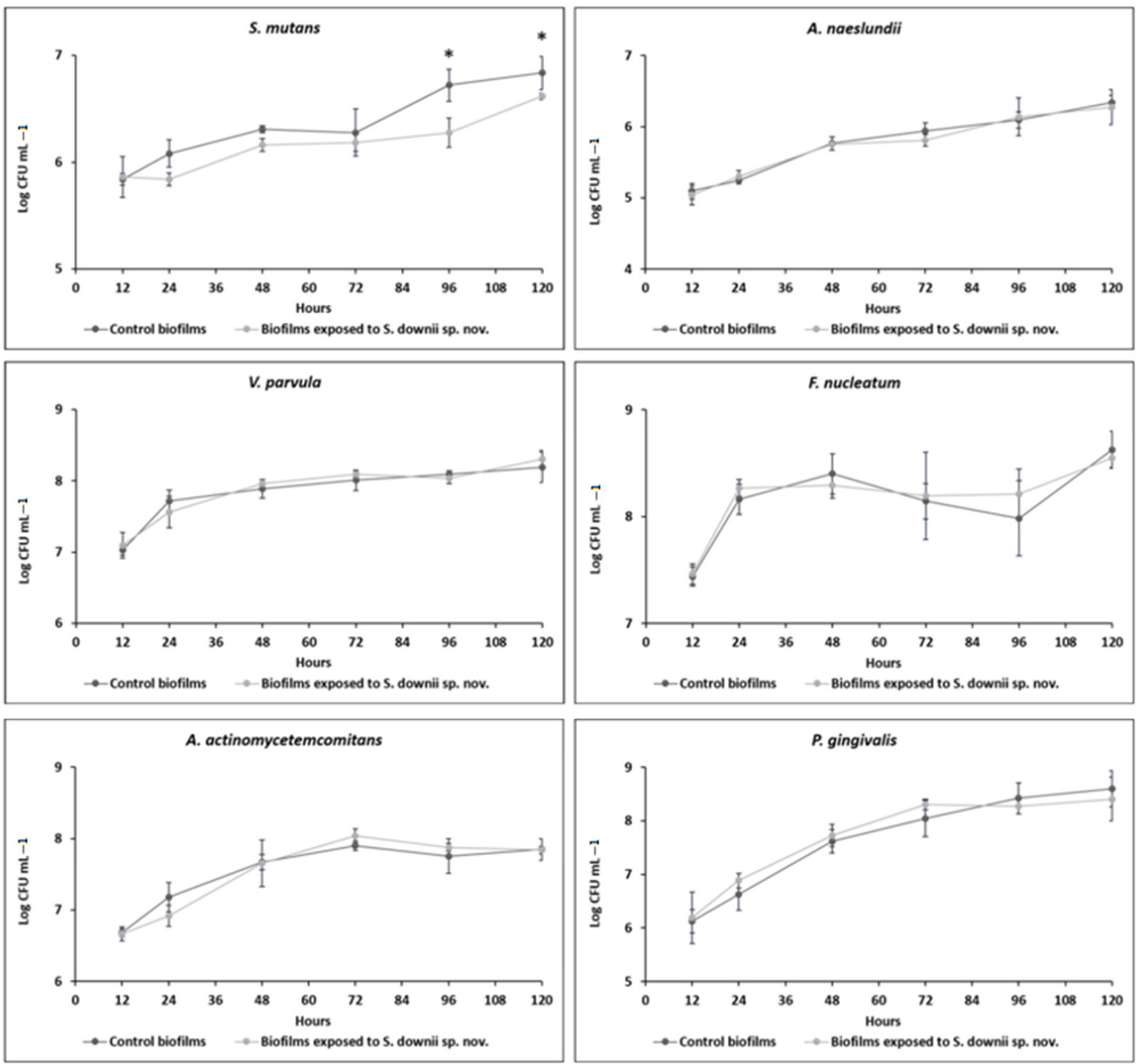

Figure 2. Kinetics of incorporation of the six selected bacterial strains in the biofilm [expressed as logarithm of Colony Forming Units per $\mathrm{mL},\left(\log \mathrm{CFU} \mathrm{mL} \mathrm{m}^{-1}\right)$ ] on the two biofilm modalities compared in the study: control biofilms (composed of Streptococcus mutans, Veillonella parvula, Actinomyces naeslundii, Fusobacterium nucleatum, Aggregatibacter actinomycetemcomitans, and Porphyromonas gingivalis) and experimental biofilms, incorporating also Streptococcus downii sp. nov. Analyses have been performed with quantitative polymerase chain reaction, in biofilms from $12 \mathrm{~h}$ to $120 \mathrm{~h}$ of incubation, using specific primers and probes directed to the $16 \mathrm{~S}$ rRNA gene. ${ }^{*} p<0.005$. 
(a)

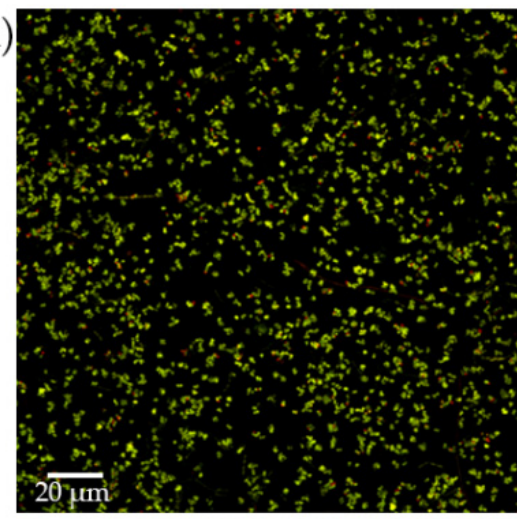

(c)

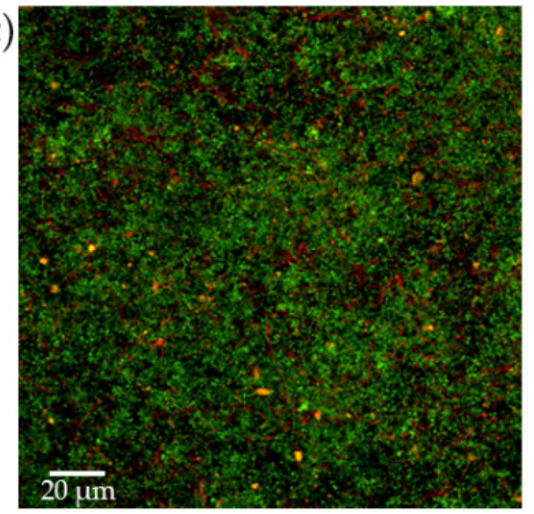

(e)

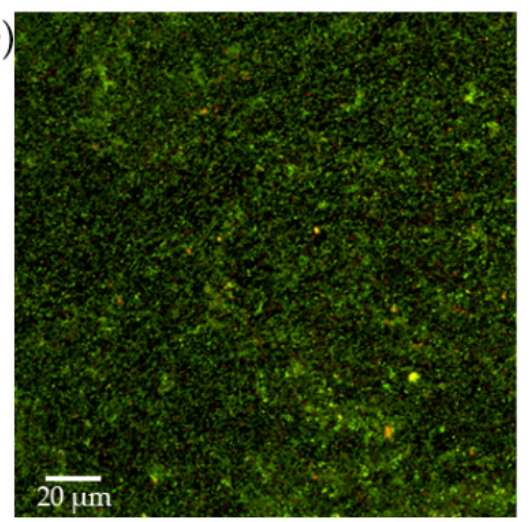

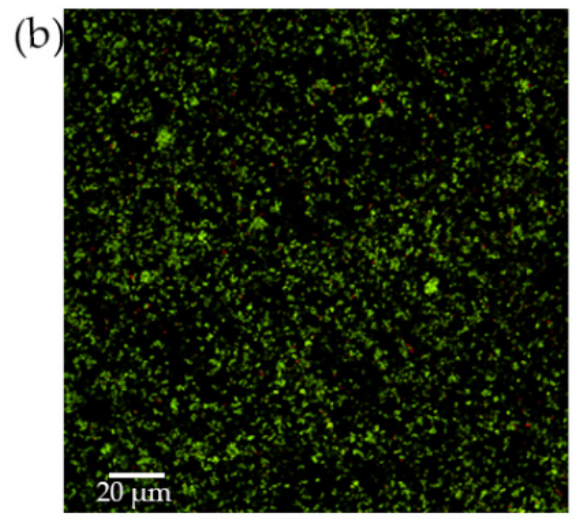

(d)

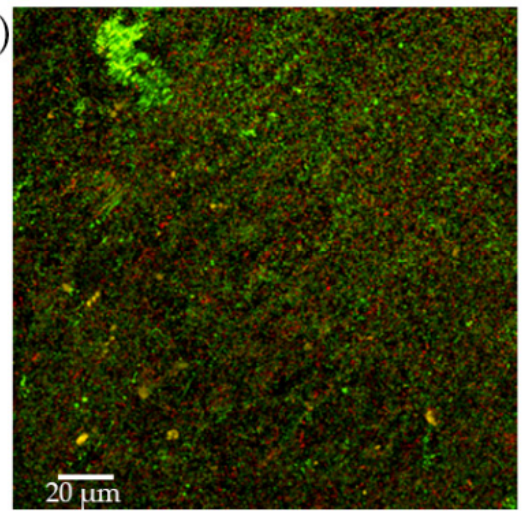

(f)

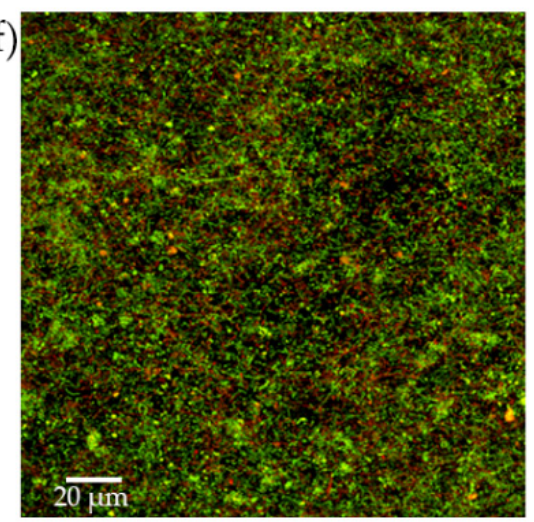

Figure 3. Confocal micrographs that represented a 2D maximum projection of the series along fixed axis of the control biofilms (a,c,e), composed by Streptococcus mutans, Veillonella parvula, Actinomyces naeslundii, Fusobacterium nucleatum, Aggregatibacter actinomycetemcomitans, and Porphyromonas gingivalis, and experimental biofilms, incorporating also Streptococcus downii sp. nov. (b,d,f), after $24 \mathrm{~h}$ $(\mathbf{a}, \mathbf{b}), 72 \mathrm{~h}(\mathbf{c}, \mathbf{d})$ and $120 \mathrm{~h}(\mathbf{e}, \mathbf{f})$ of growth. LIVE/DEAD ${ }^{\circledR}$ BacLight $^{\mathrm{TM}}$ Bacterial Viability Kit stain was used to assess the vitality of cells (live cells in green and dead cells in red color; yellowish corresponded to damage cells but still alive).

The analysis by SEM showed similar findings (Figure 4). After $120 \mathrm{~h}$ or growth, it would seem that the proportion of $S$. mutans forming chains of cocci was reduced in biofilms containing $S$. downii sp. nov., compared to grown biofilms without $S$. downii sp. nov. (Figure 4e,f). 
(a)

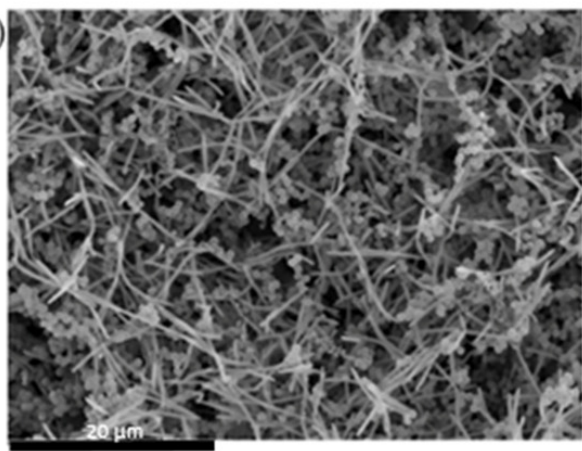

(c)

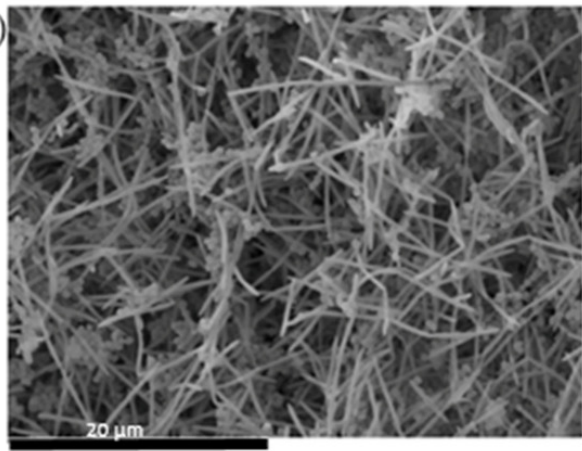

(e)

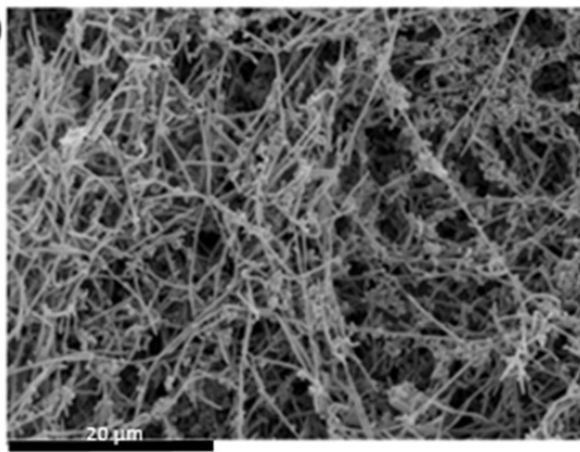

(b)

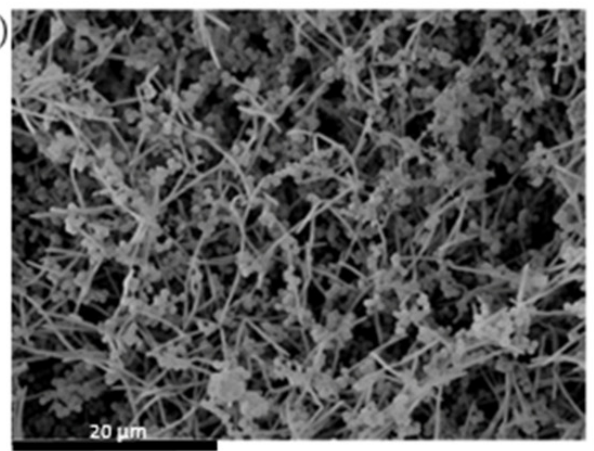

(d)

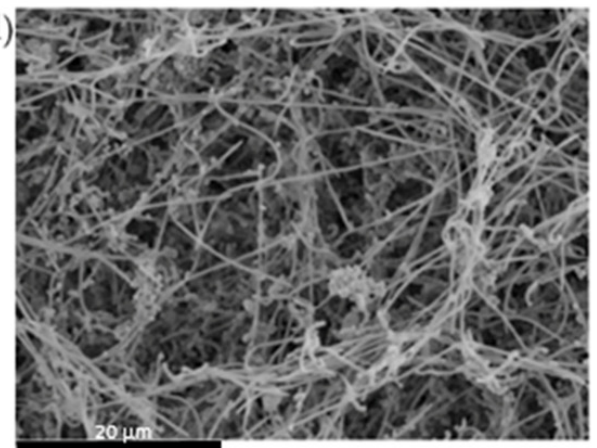

(f)

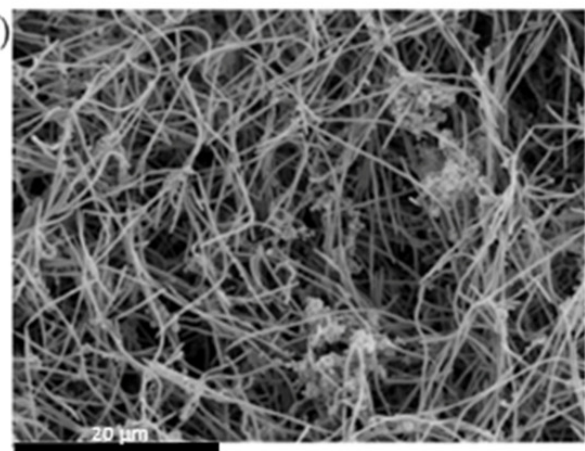

Figure 4. Scanning electron microscope images of the control biofilms (a,c,e), composed by Streptococcus mutans, Veillonella parvula, Actinomyces naeslundii, Fusobacterium nucleatum, Aggregatibacter actinomycetemcomitans and Porphyromonas gingivalis, and experimental biofilms, incorporating also Streptococcus downii sp. nov. (b,d,f), after $24 \mathrm{~h}(\mathbf{a}, \mathbf{b}), 72 \mathrm{~h}(\mathbf{c}, \mathbf{d})$ and $120 \mathrm{~h}(\mathbf{e}, \mathbf{f})$ of growth. A similar architecture of biofilms can be observed, in both presence and absence of $S$. downii sp. nov., with biofilms covering the disc surfaces with flat homogenous layers of cells, combined with bacterial clusters, showing channels inside the structure.

3.2. Antibacterial Effect of S. downii sp. nov. Against Oral Species in an Already Established in Vitro Biofilm

After $24 \mathrm{~h}$ of incubation, well-structured biofilms were developed. The presence of the six inoculated bacterial species was confirmed by $\mathrm{qPCR}$, and their live/dead ratio, measured by CLSM, was 2.0 ( $\mathrm{SD}=0.1$ ) (Figure 5).

These biofilms were then exposed to $10^{8} \mathrm{CFU} \mathrm{mL} \mathrm{m}^{-1}$ of $\mathrm{S}$. downii sp. nov. for 24 and $48 \mathrm{~h}$ and examined by CLSM (Figure 6). The obtained $24 \mathrm{~h}$ biofilms showed similar well-structured bacterial communities when compared those non-exposed versus exposed to $S$. downii sp. nov. (Figure 6a,b, respectively) and with live/dead ratio of $3.0(\mathrm{SD}=0.3$ ) and $4.2(\mathrm{SD}=1.7)$, respectively. In those exposed to $S$. downii sp. nov., a thicker live biomass could be observed, possibly caused by the additional bacteria incorporated (Figure 6a,b). After $48 \mathrm{~h}$ of exposition, in spite of having a similar biofilm structure, the percentage of dead bacteria was significantly higher in the biofilms exposed to S. downii sp. nov. 
when compared with those without $S$. downii sp. nov. (Figure $6 \mathrm{c}, \mathrm{d}$; live/dead ratio of 1.1 $(\mathrm{SD}=0.2)$ and $1.8(\mathrm{SD}=0.2)$, respectively. $)$

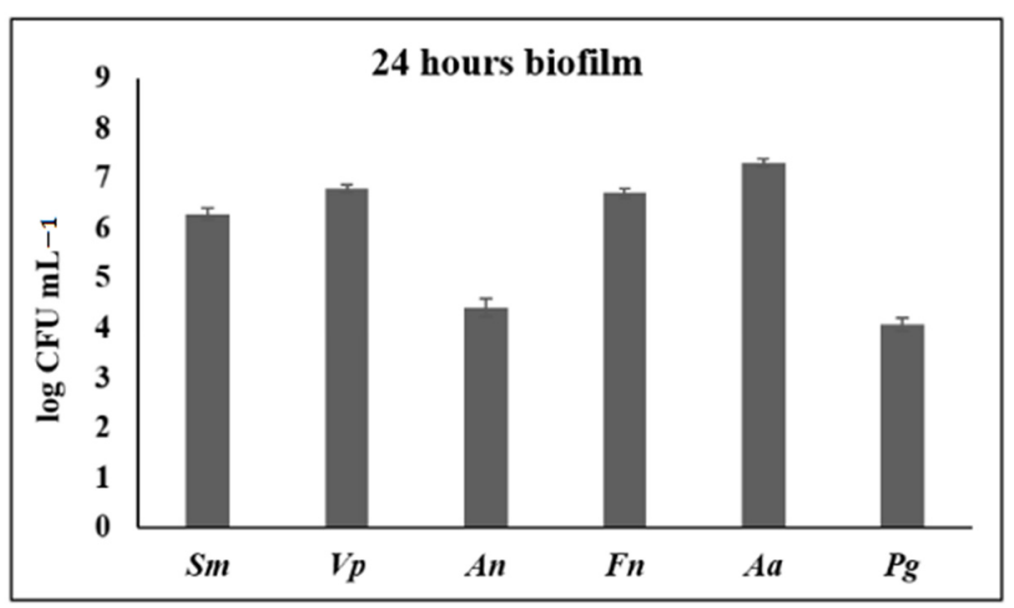

Figure 5. Analysis of 24-h biofilms by confocal laser scanning microscopy, showing a typical structure of biofilms, with bacteria in discontinuous microcolonies over hydroxyapatite surfaces, with a majority of live cells (live cells in green; dead cells in red; yellowish corresponded to damage cells but still alive); and counts (expressed as logarithm of colony forming units per $\mathrm{mL}^{\mathrm{C}} \mathrm{CFU} \mathrm{mL} \mathrm{m}^{-1}$ ) of Streptococcus mutans (Sm), Veillonella parvula (Vp), Actinomyces naeslundii (An), Fusobacterium nucleatum $(F n)$, Aggregatibacter actinomycetemcomitans (Aa), and Porphyromonas gingivalis $(P g)$.

(a)

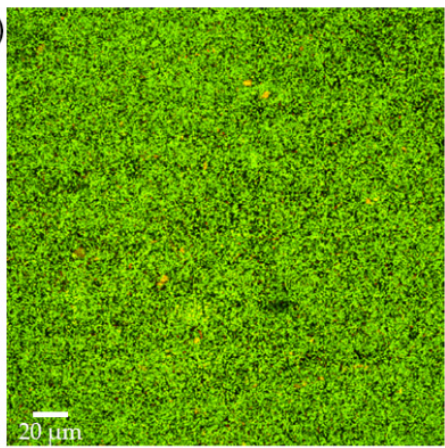

(c)

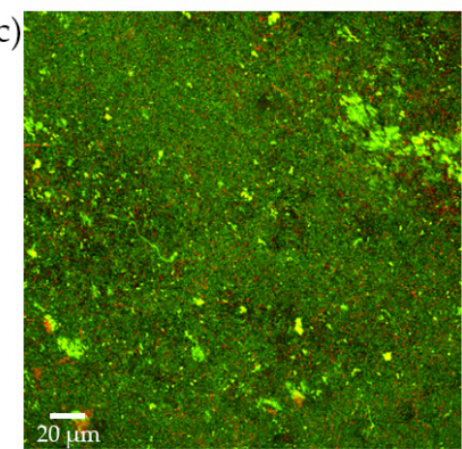

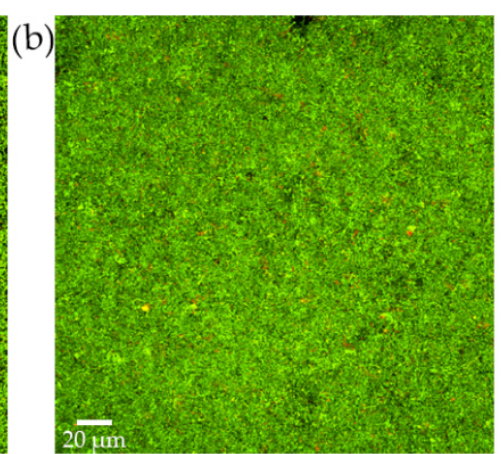

(d)

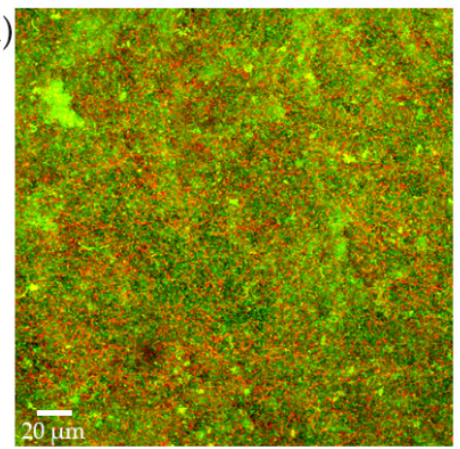

Figure 6. Analysis by confocal laser scanning microscopy of: (a,b) 24-h biofilms exposed for $24 \mathrm{~h}$ to $1 \mathrm{~mL}$ of brain heart infusion (BHI) medium (control biofilms) and to $1 \mathrm{~mL}$ of $10^{8}$ colony forming units (CFU) $\mathrm{mL}^{-1}$ of $S$. downii sp. nov. in fresh BHI medium (exposed biofilms), respectively; (c,d) 24-h biofilms exposed for $48 \mathrm{~h}$ to $1 \mathrm{~mL}$ of $\mathrm{BHI}$ medium (control biofilms) and to $1 \mathrm{~mL}$ of $10^{8} \mathrm{CFU}$ $\mathrm{mL}^{-1}$ of $S$. downii sp. nov., in fresh BHI medium (exposed biofilms), respectively.

Figure 7 depicts the concentration (expressed in CFU mL $\mathrm{mL}^{-1}$ ) of the six inoculated bacteria when comparing those biofilms exposed and non-exposed to $S$. downii sp. nov. for 
24 and $48 \mathrm{~h}$. After $24 \mathrm{~h}$ of contact with $S$. downii sp. nov., the concentration of S. mutans $(p=0.019)$ and A. actinomycetemcomitans $(p=0.020)$ were significantly reduced, when compared to non-exposed biofilms (Figure 7a). After $48 \mathrm{~h}$ of contact, a similar tendency was observed, but with statistically significant higher concentrations for A. naeslundii, in exposed biofilms ( $p=0.003$ ) (Figure $7 \mathrm{~b}$ ).
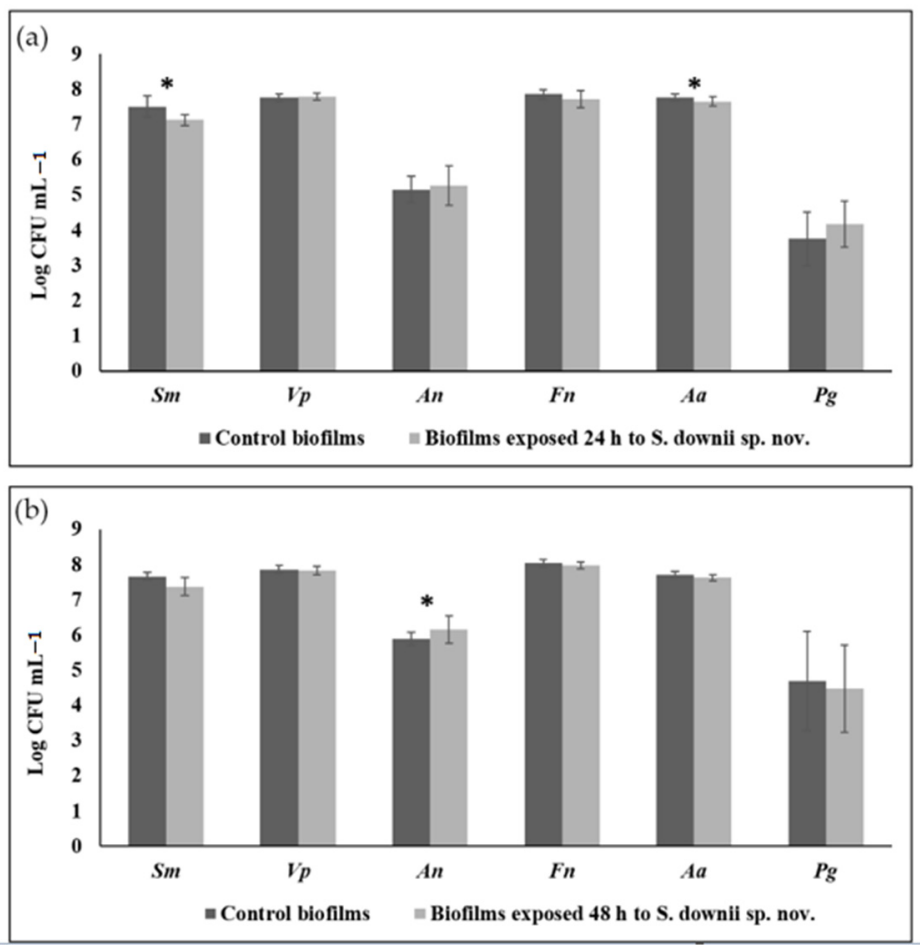

Figure 7. Counts (expressed as logarithm of colony forming units per $\mathrm{mL}, \mathrm{CFU} / \mathrm{mL}$ ) of Streptococcus mutans (Sm), Veillonella parvula (Vp), Actinomyces naeslundii (An), Fusobacterium nucleatum (Fn), Aggregatibacter actinomycetemcomitans $(\mathrm{Aa})$, and Porphyromonas gingivalis $(\mathrm{Pg})$ in biofilms using specific primers and probes directed to the $16 \mathrm{~S}$ rRNA gene: (a) $24-\mathrm{h}$ biofilms after contact with $10^{8} \mathrm{CFU} / \mathrm{mL}$ of $S$. downii sp. nov. for $24 \mathrm{~h}$ more; (b) 24 -h biofilms after contact with $10^{8} \mathrm{CFU} / \mathrm{mL}$ of $S$. downii sp. nov. for $48 \mathrm{~h}$ more. ${ }^{*} p<0.005$.

With longer time of incubation (from 24 to $48 \mathrm{~h}$ ), the concentration of the selected bacteria increased in both types of biofilms, but for $P$. gingivalis, a significant increase ( $p=0.018)$ was observed in non-exposed biofilms, while the increase in exposed biofilms was not statistically significant $(p=0.395)$. A similar trend was observed for $V$. parvula ( $p=0.050$ in non-exposed biofilms and $p=0.295$ in exposed biofilms, respectively).

\section{Discussion}

The novel species $S$. downii sp. nov. has been recently isolated from a supragingival dental biofilm sample of an individual with Down syndrome [29]. The orofacial and skeletal developmental disturbances associated with Down syndrome contribute to frequent oral conditions and diseases in these patients, as periodontal diseases, malocclusion, mouth breathing, macroglossia, delayed teeth eruption, missing and malformed teeth, microdontia, diastema, and bruxism [31]. In spite of this, Down syndrome individuals have shown significantly lower prevalence of dental caries when compared with matched individuals without the syndrome [31]. In this regard, previous evidence has indicated antibacterial activity of $S$. downii sp. nov. against pathogens involved, not only in caries, but also in periodontal diseases, carried out by inhibition assays on solid culture medium [29].

Based on the previous findings, and in order to provide additional information, but with a model that better resembles what occurs in the oral cavity (bacteria organized 
in biofilms), the potential effect on oral health of $S$. downii sp. nov. was studied using a validated in vitro biofilm model. The present manuscript describes the in vitro antibacterial and anti-biofilm effects of $S$. downii sp. nov. when inoculated with oral bacteria included in a multispecies biofilm. Although there was no significant impact in the early stages of biofilm formation, during the stationary phase of biofilm growth, there was a significant reduction in the growth of $S$. mutans and $A$. actinomycetemcomitans that was evident with qPCR analysis.

This antibacterial activity on oral bacteria forming biofilms are in accordance with previous studies reported antibacterial activity of $S$. mitis group [23-25]. Similarly, other streptococci have demonstrated an impact on periodontal pathogens [22,28,32-36]. However, most of these in vitro studies were done using planktonic in vitro cultures, unlike the present study, carried out with an in vitro multispecies biofilm model. This difference may be relevant since not only translates closer the real bacterial growth in the oral cavity, but also demonstrates the antibacterial effect in an environment where these bacteria are more tolerant against antimicrobial agents. Another reason for choosing this in vitro biofilm model was to test the potential of the tested bacteria to adhere to oral surfaces, which can only be mimicked in such a model. Finally, the role of dental biofilms in the etiology of caries and periodontal diseases justifies the use of the present validated in vitro biofilm model [30], which was modified by changing the early colonizer S. mutans instead of $S$. oralis, since $S$. mutans has demonstrated a stronger association with both the onset and progression of dental caries [37-39].

When assessing the anti-biofilm capacity of $S$. downii sp. nov., an indigenous species of the oral cavity in subjects with Down syndrome, it was observed that it was able to effectively colonize the in vitro developed biofilms, without interfering with its structure and bacterial composition, since it did not affect the kinetics of colonization of secondary colonizers ( $V$. parvula and A. naeslundii) or periodontal pathogens (F. nucleatum, A. actinomycetemcomitans, and P. gingivalis). However, its presence significantly interfered with the colonization kinetics of $S$. mutans, suggesting that the presence $S$. downii sp. nov. may control $S$. mutans levels, thus promoting health compatible biofilms or modifying their pathogenic potential [40].

Our findings agree with previous publications, which describe that some bacterial species, closely related to $S$. downii sp. nov., and isolated from caries-free subjects, exhibited antibacterial capacity against $S$. mutans. Bao et al. and Tong et al. [32,33] reported the inhibition of S. mutans by Streptococcus oligofermentans, due to the production of hydrogen peroxide, while Ogawa et al. [34], observed that Streptococcus salivarius inhibited the development of $S$. mutans biofilms, via bacteriocin production. More recently, the antibacterial capacity of Streptococcus A12 [35] and S. dentisani [22] against S. mutans was also described. Other studies reported that exogenous bacteria from the oral cavity could affect $S$. mutans, such as Bifidobacterium spp. isolated from human intestine [41], Lactobacillus reuteri strains, which were able to inhibit the growth of $S$. mutans in different degrees [42] or different Lactobacillus spp., which exhibits a notable degree of antagonism against S. mutans [41,43].

In regard to the ability to inhibit the formation and/or biofilm growth, as observed in the present research, this has been documented for other oral exogenous bacteria, including Enterococcus faecium WB2000, Bifidobacterium adolescentis SPM1005, or heat-inactivated Bifidobacterium BB12 [44-46]. Söderling et al. [47] observed that the probiotic strains L. reuteri SD2112 and L. reuteri PTA5289, Lactobacillus rhamnosus GG, and Lactobacillus plantarum 229v inhibited $S$. mutans biofilm formation on glass surfaces. Marttinem et al. [48] confirmed that $L$. reuteri ATCC PTA5289 could interfere with the adhesion of $S$. mutans to HA discs and inhibited biofilm formation. Lin et al. [49] refereed to the ability to inhibit S. mutans formation and biofilm growth on glass surfaces of other Lactobacillus strains, including L. rhamnosus HN001, L. plantarum ST-III, Lactobacillus casei strain Shirota, L. casei LC01, and Lactobacillus paracasei Lpc-37.

When assessing the antibacterial capacity of $S$. downii sp. nov. against a well-structured biofilm, this bacterial species was able to induced a significant lower concentrations of 
S. mutans $(p=0.019)$ and $A$. actinomycetemcomitans $(p=0.020)$, significant higher concentrations of $A$. naeslundii ( $p=0.003$ ) and prevented a statistically significant increment for $P$. gingivalis and V. parvula ( $p=0.395$ and $\mathrm{p}=0.295$, respectively), compared to non-exposed biofilms. These results may suggest a potential probiotic effect of $S$. downii sp. nov. in the maintenance of oral homeostasis, decreasing the amounts of potential pathogenic species, and stimulating the growth of health-associated, potentially beneficial bacteria, such as A. naeslundii.

In periodontitis, both indigenous and exogenous bacterial strains have been in vivo and in vitro assessed, testing the hypothesis that they could help in the suppression of periodontal pathogens by competitive exclusion mechanisms and/or via the production of antimicrobial substances $[28,36,50]$. In vitro studies have shown positive results for different endogenous bacterial strains. S. dentisani showing inhibition of growth of periodontal pathogens and other pathogens implicated in root canals infections by the production of antimicrobial substances, although the study was conducted in planktonic in vitro cultures [22]. S. mitis demonstrated a successful antagonism in the adhesion of P. gingivalis [23], and also reduced the growth of $P$. gingivalis in presence of salivary bifidobacteria by reducing growth factor(s) from the environment [26]. Among exogenous strains, in vitro viability of $A$. actinomycetemcomitans was affected by human intestinal Bifidobacterium spp. [41]. Bdellovibrio bacteriovorus has been shown to significantly reduce the number of viable A. actinomycetemcomitans, both in planktonic and mono-species in vitro biofilm cultures [51]. However, it was observed that the efficiency decreased as the complexity of the model increased, i.e., with a model including six bacterial species ( $P$. intermedia, A. actinomycetemcomitans, P. gingivalis, F. nucleatum, S. mitis, and A. naeslundii) [52].

This study presents clear limitations: an in vitro biofilm model consisting of six bacterial species has been used, and the effects of $S$. downii sp. nov. could be less evident in more diverse biofilms, closer to in vivo conditions; the application of the present findings could be limited due if there were relevant differences in the oral microbiota among Down syndrome subjects and other systemically healthy individuals and/or periodontitis patients $[53,54]$, in whom $S$. downii sp. nov. may exhibit less capacity to colonize oral biofilms in vivo. The selected biofilm model consists in a common consortium of bacteria, including commensal bacteria and common periodontal pathogens strongly associated with periodontitis and caries, and the present study has shown, for the first time, antibacterial and antibiofilm activities of the tested novel species; thus, more studies are granted to better understand the mechanisms of action behind these findings.

\section{Conclusions}

In summary, the results of the present study have shown that an indigenous bacterial strain, S. downii sp. nov., had a moderate impact in oral biofilm formation and composition, as tested in a validated multi-species in vitro biofilm model. Firstly, it was shown that it was able to colonize the formed biofilms; secondly, and although the structural development was not affected by the presence of $S$. downii sp. nov., significantly lower amounts of A. actinomycetemcomitans (a periodontal pathogen, strongly associated with periodontitis) and of $S$. mutans (strongly associated with caries) were incorporated in the biofilms, in the presence of $S$. downii sp. nov. The present results, together with the previous findings showing $\alpha$ - and $\beta$-galactosidase activities of $S$. downii sp. nov. [29], which indicates that $S$. downii sp. nov. can use several saccharides as carbon source, including lactose, represents an advantage for its potential application as an oral probiotic [55].

Author Contributions: Conceptualization, M.C.S., P.D., M.Á., M.S. and D.H.; methodology, M.C.S., M.C., L.M-L., M.S. and D.H.; investigation, M.C.S., M.C., L.M.-L., J.L. and D.H.; writing-original draft preparation, M.C., M.C.S., P.D. and D.H.; writing-review and editing, L.M.-L., M.Á., J.L., M.S., P.D. and D.H.; supervision, D.H. and M.S.; project administration, P.D. and D.H.; funding acquisition, P.D., M.Á., and M.S. All authors have read and agreed to the published version of the manuscript. 
Funding: This research was co-funded by Xunta de Galicia under Ignicia Programme, Axencia Galega de Innovación, GAIN (12/08/2016; GRANT_NUMBER: IN855A). The participation of M.C. Sánchez in the project occurred within the activities of the Extraordinary Chair of DENTAID, University Complutense of Madrid, Spain.

Institutional Review Board Statement: Not applicable.

Informed Consent Statement: Not applicable.

Data Availability Statement: Data available on request due to restrictions. The data presented in this study are available on request from the corresponding author. The data are not publicly available due to privacy issues.

Acknowledgments: CLSM analyses were carried out at the Centre of Microscopy and Cytometry from the University Complutense of Madrid, Spain and the SEM at the ICTS National Centre of Electronic Microscopy, from the University Complutense of Madrid, Spain.

Conflicts of Interest: The authors declare no conflict of interest.

\section{References}

1. Griffen, A.L.; Beall, C.J.; Campbell, J.H.; Firestone, N.D.; Kumar, P.S.; Yang, Z.K.; Podar, M.; Leys, E.J. Distinct and complex bacterial profiles in human periodontitis and health revealed by $16 \mathrm{~S}$ pyrosequencing. ISME J. 2012, 6, 1176-1185. [CrossRef]

2. Deo, P.N.; Deshmukh, R. Oral microbiome: Unveiling the fundamentals. JOMFP 2019, 23, 122-128.

3. Human Microbiome Project Consortium. Structure, function and diversity of the healthy human microbiome. Nature 2012, 486, 207-214. [CrossRef] [PubMed]

4. Kerr, J.E.; Tribble, G.D. Salivary Diagnostics and the Oral Microbiome. In Advances in Salivary Diagnostics; Streckfus, C.F., Ed.; Springer: Berlin/Heidelberg, Germany, 2015; pp. 83-119.

5. Teles, R.; Teles, F.; Frias-Lopez, J.; Paster, B.; Haffajee, A. Lessons learned and unlearned in periodontal microbiology. Periodontol. 2000 2013, 62, 95-162. [CrossRef] [PubMed]

6. Herrera, D.; Alonso, B.; Leon, R.; Roldan, S.; Sanz, M. Antimicrobial therapy in periodontitis: The use of systemic antimicrobials against the subgingival biofilm. J Clin Periodontol. 2008, 35 (Suppl. 8), 45-66. [CrossRef]

7. Serrano, J.; Escribano, M.; Roldan, S.; Martin, C.; Herrera, D. Efficacy of adjunctive anti-plaque chemical agents in managing gingivitis: A systematic review and meta-analysis. J. Clin. Periodontol. 2015, 42, S106-S138. [CrossRef]

8. Haffajee, A.D.; Uzel, N.G.; Arguello, E.I.; Torresyap, G.; Guerrero, D.M.; Socransky, S.S. Clinical and microbiological changes associated with the use of combined antimicrobial therapies to treat "refractory" periodontitis. J. Clin. Periodontol. 2004, 31, 869-877. [CrossRef]

9. Bizzarro, S.; Laine, M.L.; Buijs, M.J.; Brandt, B.W.; Crielaard, W.; Loos, B.G.; Zaura, E. Microbial profiles at baseline and not the use of antibiotics determine the clinical outcome of the treatment of chronic periodontitis. Sci. Rep. 2016, 6, 20205. [CrossRef]

10. Ikram, S.; Hassan, N.; Raffat, M.A.; Mirza, S.; Akram, Z. Systematic review and meta-analysis of double-blind, placebo-controlled, randomized clinical trials using probiotics in chronic periodontitis. J. Investig. Clin. Dent. 2018, 9, e12338. [CrossRef]

11. Matsubara, V.H.; Bandara, H.M.; Ishikawa, K.H.; Mayer, M.P.; Samaranayake, L.P. The role of probiotic bacteria in managing periodontal disease: A systematic review. Expert Rev. Anti Infect. Ther. 2016, 14, 643-655. [CrossRef]

12. Iniesta, M.; Herrera, D.; Montero, E.; Zurbriggen, M.; Matos, A.R.; Marin, M.J.; Sanchez-Beltran, M.C.; Llama-Palacio, A.; Sanz, M. Probiotic effects of orally administered Lactobacillus reuteri-containing tablets on the subgingival and salivary microbiota in patients with gingivitis. A randomized clinical trial. J. Clin. Periodontol. 2012, 39, 736-744. [CrossRef] [PubMed]

13. Vicario, M.; Santos, A.; Violant, D.; Nart, J.; Giner, L. Clinical changes in periodontal subjects with the probiotic Lactobacillus reuteri Prodentis: A preliminary randomized clinical trial. Acta Odontol. Scand. 2013, 71, 813-819. [CrossRef] [PubMed]

14. Vivekananda, M.R.; Vandana, K.L.; Bhat, K.G. Effect of the probiotic Lactobacilli reuteri (Prodentis) in the management of periodontal disease: A preliminary randomized clinical trial. J. Oral Microbiol. 2010, 2, 5344. [CrossRef] [PubMed]

15. Morales, A.; Carvajal, P.; Silva, N.; Hernandez, M.; Godoy, C.; Rodriguez, G.; Cabello, R.; Garcia-Sesnich, J.; Hoare, A.; Diaz, P.I.; et al. Clinical Effects of Lactobacillus rhamnosus in Non-Surgical Treatment of Chronic Periodontitis: A Randomized PlaceboControlled Trial With 1-Year Follow-Up. J. Periodontol. 2016, 87, 944-952. [CrossRef]

16. Teughels, W.; Durukan, A.; Ozcelik, O.; Pauwels, M.; Quirynen, M.; Haytac, M.C. Clinical and microbiological effects of Lactobacillus reuteri probiotics in the treatment of chronic periodontitis: A randomized placebo-controlled study. J. Clin. Periodontol. 2013, 40, 1025-1035. [CrossRef] [PubMed]

17. Krasse, P.; Carlsson, B.; Dahl, C.; Paulsson, A.; Nilsson, A.; Sinkiewicz, G. Decreased gum bleeding and reduced gingivitis by the probiotic Lactobacillus reuteri. Swed. Dent. J. 2006, 30, 55-60. [PubMed]

18. Twetman, S.; Derawi, B.; Keller, M.; Ekstrand, K.; Yucel-Lindberg, T.; Stecksen-Blicks, C. Short-term effect of chewing gums containing probiotic Lactobacillus reuteri on the levels of inflammatory mediators in gingival crevicular fluid. Acta Odontol. Scand. 2009, 67, 19-24. [CrossRef] [PubMed] 
19. Mayanagi, G.; Kimura, M.; Nakaya, S.; Hirata, H.; Sakamoto, M.; Benno, Y.; Shimauchi, H. Probiotic effects of orally administered Lactobacillus salivarius WB21-containing tablets on periodontopathic bacteria: A double-blinded, placebo-controlled, randomized clinical trial. J. Clin. Periodontol. 2009, 36, 506-513. [CrossRef] [PubMed]

20. Shimauchi, H.; Mayanagi, G.; Nakaya, S.; Minamibuchi, M.; Ito, Y.; Yamaki, K.; Hirata, H. Improvement of periodontal condition by probiotics with Lactobacillus salivarius WB21: A randomized, double-blind, placebo-controlled study. J. Clin. Periodontol. 2008, 35, 897-905. [CrossRef]

21. Hoare, A.; Marsh, P.D.; Diaz, P.I. Ecological Therapeutic Opportunities for Oral Diseases. Microbiol. Spectr. 2017, 5, $235-265$.

22. Lopez-Lopez, A.; Camelo-Castillo, A.; Ferrer, M.D.; Simon-Soro, A.; Mira, A. Health-Associated Niche Inhabitants as Oral Probiotics: The Case of Streptococcus dentisani. Front. Microbiol. 2017, 8, 379. [CrossRef] [PubMed]

23. Van Hoogmoed, C.G.; Geertsema-Doornbusch, G.I.; Teughels, W.; Quirynen, M.; Busscher, H.J.; Van der Mei, H.C. Reduction of periodontal pathogens adhesion by antagonistic strains. Oral Microbiol. Immunol. 2008, 23, 43-48. [CrossRef] [PubMed]

24. Teughels, W.; Kinder Haake, S.; Sliepen, I.; Pauwels, M.; Van Eldere, J.; Cassiman, J.J.; Quirynen, M. Bacteria interfere with A. actinomycetemcomitans colonization. J. Dent. Res. 2007, 86, 611-617. [CrossRef] [PubMed]

25. Sliepen, I.; Van Essche, M.; Loozen, G.; Van Eldere, J.; Quirynen, M.; Teughels, W. Interference with Aggregatibacter actinomycetemcomitans: Colonization of epithelial cells under hydrodynamic conditions. Oral Microbiol. Immunol. 2009, 24, 390-395. [CrossRef] [PubMed]

26. Hojo, K.; Nagaoka, S.; Murata, S.; Taketomo, N.; Ohshima, T.; Maeda, N. Reduction of vitamin K concentration by salivary Bifidobacterium strains and their possible nutritional competition with Porphyromonas gingivalis. J. Appl. Microbiol. 2007, 103, 1969-1974. [CrossRef] [PubMed]

27. Llena, C.; Almarche, A.; Mira, A.; Lopez, M.A. Antimicrobial efficacy of the supernatant of Streptococcus dentisani against microorganisms implicated in root canal infections. J. Oral Sci. 2019, 61, 184-194. [CrossRef]

28. Esteban-Fernandez, A.; Ferrer, M.D.; Zorraquin-Pena, I.; Lopez-Lopez, A.; Moreno-Arribas, M.V.; Mira, A. In vitro beneficial effects of Streptococcus dentisani as potential oral probiotic for periodontal diseases. J. Periodontol. 2019, 90, 1346-1355. [CrossRef] [PubMed]

29. Martinez-Lamas, L.; Limeres-Posse, J.; Diz-Dios, P.; Alvarez-Fernandez, M. Streptococcus downii sp. nov., isolated from the oral cavity of a teenager with Down syndrome. Int. J. Syst. Evol. Microbiol. 2020, 70, 4098-4104. [CrossRef]

30. Sanchez, M.C.; Llama-Palacios, A.; Blanc, V.; Leon, R.; Herrera, D.; Sanz, M. Structure, viability and bacterial kinetics of an in vitro biofilm model using six bacteria from the subgingival microbiota. J. Periodontal. Res. 2011, 46, 252-260. [CrossRef]

31. Deps, T.D.; Angelo, G.L.; Martins, C.C.; Paiva, S.M.; Pordeus, I.A.; Borges-Oliveira, A.C. Association between Dental Caries and Down Syndrome: A Systematic Review and Meta-Analysis. PLoS ONE 2015, 10, e0127484.

32. Bao, X.; de Soet, J.J.; Tong, H.; Gao, X.; He, L.; van Loveren, C.; Deng, D.M. Streptococcus oligofermentans Inhibits Streptococcus mutans in Biofilms at Both Neutral pH and Cariogenic Conditions. PLoS ONE 2015, 10, e0130962. [CrossRef]

33. Tong, H.; Chen, W.; Merritt, J.; Qi, F.; Shi, W.; Dong, X. Streptococcus oligofermentans inhibits Streptococcus mutans through conversion of lactic acid into inhibitory $\mathrm{H} 2 \mathrm{O} 2$ : A possible counteroffensive strategy for interspecies competition. Mol. Microbiol. 2007, 63, 872-880. [CrossRef]

34. Ogawa, A.; Furukawa, S.; Fujita, S.; Mitobe, J.; Kawarai, T.; Narisawa, N.; Sekizuka, T.; Kuroda, M.; Ochiai, K.; Ogihara, H.; et al. Inhibition of Streptococcus mutans biofilm formation by Streptococcus salivarius FruA. Appl. Environ. Microbiol. 2011, 77, 1572-1580. [CrossRef]

35. Huang, X.; Palmer, S.R.; Ahn, S.J.; Richards, V.P.; Williams, M.L.; Nascimento, M.M.; Burne, R.A. A Highly Arginolytic Streptococcus Species That Potently Antagonizes Streptococcus mutans. Appl. Environ. Microbiol. 2016, 82, 2187-2201. [CrossRef] [PubMed]

36. Ferrer, M.D.; Lopez-Lopez, A.; Nicolescu, T.; Perez-Vilaplana, S.; Boix-Amoros, A.; Dzidic, M.; Garcia, S.; Artacho, A.; Llena, C.; Mira, A. Topic Application of the Probiotic Streptococcus dentisani Improves Clinical and Microbiological Parameters Associated With Oral Health. Front. Cell Infect. Microbiol. 2020, 10, 465. [CrossRef]

37. Gross, E.L.; Beall, C.J.; Kutsch, S.R.; Firestone, N.D.; Leys, E.J.; Griffen, A.L. Beyond Streptococcus mutans: Dental caries onset linked to multiple species by $16 \mathrm{~S}$ rRNA community analysis. PLoS ONE 2012, 7, e47722. [CrossRef] [PubMed]

38. Becker, M.R.; Paster, B.J.; Leys, E.J.; Moeschberger, M.L.; Kenyon, S.G.; Galvin, J.L.; Boches, S.K.; Dewhirst, F.E.; Griffen, A.L. Molecular analysis of bacterial species associated with childhood caries. J. Clin. Microbiol. 2002, 40, 1001-1009. [CrossRef] [PubMed]

39. Loesche, W.J.; Rowan, J.; Straffon, L.H.; Loos, P.J. Association of Streptococcus mutants with human dental decay. Infect. Immun. 1975, 11, 1252-1260. [CrossRef] [PubMed]

40. Aas, J.A.; Griffen, A.L.; Dardis, S.R.; Lee, A.M.; Olsen, I.; Dewhirst, F.E.; Leys, E.J.; Paster, B.J. Bacteria of dental caries in primary and permanent teeth in children and young adults. J. Clin. Microbiol. 2008, 46, 1407-1417. [CrossRef]

41. Lee, S.H.; Kim, Y.J. A comparative study of the effect of probiotics on cariogenic biofilm model for preventing dental caries. Arch. Microbiol. 2014, 196, 601-609. [CrossRef]

42. Samot, J.; Badet, C. Antibacterial activity of probiotic candidates for oral health. Anaerobe 2013, 19, 34-38. [CrossRef] [PubMed]

43. Tong, Z.; Zhou, L.; Li, J.; Kuang, R.; Lin, Y.; Ni, L. An in vitro investigation of Lactococcus lactis antagonizing cariogenic bacterium Streptococcus mutans. Arch. Oral Biol. 2012, 57, 376-382. [CrossRef] 
44. $\quad$ Lee, D.K.; Park, S.Y.; An, H.M.; Kim, J.R.; Kim, M.J.; Lee, S.W.; Cha, M.K.; Kim, S.A.; Chung, M.J.; Lee, K.O.; et al. Antimicrobial activity of Bifidobacterium spp. isolated from healthy adult Koreans against cariogenic microflora. Arch. Oral. Biol. 2011, 56, 1047-1054. [CrossRef]

45. Schwendicke, F.; Horb, K.; Kneist, S.; Dorfer, C.; Paris, S. Effects of heat-inactivated Bifidobacterium BB12 on cariogenicity of Streptococcus mutans in vitro. Arch. Oral Biol. 2014, 59, 1384-1390. [CrossRef]

46. Suzuki, N.; Yoneda, M.; Hatano, Y.; Iwamoto, T.; Masuo, Y.; Hirofuji, T. Enterococcus faecium WB2000 Inhibits Biofilm Formation by Oral Cariogenic Streptococci. Int. J. Dent. 2011, 2011, 834151. [CrossRef]

47. Soderling, E.M.; Marttinen, A.M.; Haukioja, A.L. Probiotic lactobacilli interfere with Streptococcus mutans biofilm formation in vitro. Curr. Microbiol. 2011, 62, 618-622. [CrossRef] [PubMed]

48. Marttinen, A.M.; Haukioja, A.L.; Keskin, M.; Soderling, E.M. Effects of Lactobacillus reuteri PTA 5289 and L. paracasei DSMZ16671 on the adhesion and biofilm formation of Streptococcus mutans. Curr. Microbiol. 2013, 67, 193-199. [CrossRef]

49. Lin, X.; Chen, X.; Chen, Y.; Jiang, W.; Chen, H. The effect of five probiotic lactobacilli strains on the growth and biofilm formation of Streptococcus mutans. Oral Dis. 2015, 21, e128-e134. [CrossRef]

50. Teughels, W.; Loozen, G.; Quirynen, M. Do probiotics offer opportunities to manipulate the periodontal oral microbiota? J. Clin. Periodontol. 2011, 38, 159-177. [CrossRef] [PubMed]

51. Van Essche, M.; Quirynen, M.; Sliepen, I.; Van Eldere, J.; Teughels, W. Bdellovibrio bacteriovorus attacks Aggregatibacter actinomycetemcomitans. J. Dent. Res. 2009, 88, 182-186. [CrossRef] [PubMed]

52. Loozen, G.; Boon, N.; Pauwels, M.; Slomka, V.; Rodrigues Herrero, E.; Quirynen, M.; Teughels, W. Effect of Bdellovibrio bacteriovorus HD100 on multispecies oral communities. Anaerobe 2015, 35, 45-53. [CrossRef] [PubMed]

53. Cuenca, M.; Marín, M.J.; Nóvoa, L.; O’Connor, A.; Sánchez, M.C.; Blanco, J.; Limeres, J.; Sanz, M.; Diz, P.; Herrera, D. Periodontal Condition and Subgingival Microbiota Characterization in Subjects with Down Syndrome. Appl. Sci. 2021, 11, 778. [CrossRef]

54. Novoa, L.; Sanchez, M.D.C.; Blanco, J.; Limeres, J.; Cuenca, M.; Marin, M.J.; Sanz, M.; Herrera, D.; Diz, P. The Subgingival Microbiome in Patients with Down Syndrome and Periodontitis. J. Clin. Med. 2020, 9, 2482. [CrossRef]

55. Fernandez, M.; Hudson, J.A.; Korpela, R.; de los Reyes-Gavilan, C.G. Impact on human health of microorganisms present in fermented dairy products: An overview. Biomed. Res. Int. 2015, 2015, 412714. [CrossRef] 